\title{
Antonio Doménech-Carbó joins as topical editor for "Solid State and Solution Electroanalysis"
}

\author{
Fritz Scholz
}

Received: 26 July 2012 / Accepted: 26 July 2012 /Published online: 5 August 2012

(C) Springer-Verlag 2012

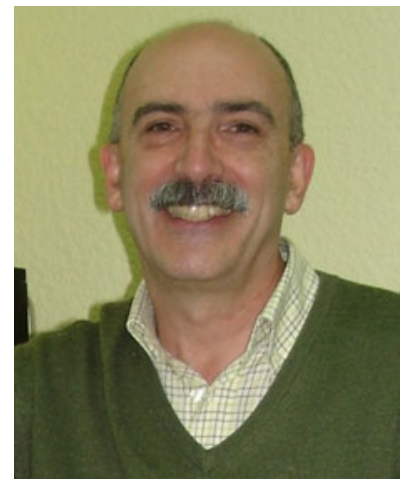

The publisher Springer and the editors of the Journal of Solid State Electrochemistry are pleased to announce that Professor Antonio Doménech-Carbó from the University of Valencia, Spain, joins as topical editor responsible for "Solid State and Solution Electroanalysis". Professor Doménech-Carbó will help the journal to deal with the strongly increasing number of manuscripts devoted to analytical applications. In this respect, it needs to be mentioned here again that the journal is focussed on solid state electrochemistry and solid electrodes. Analytical papers are published when there is a strong connection to solid state features of the electrodes. Exceptions are only considered in case of special issues.

Professor Doménech-Carbó is a highly prolific scientist who is both experienced in electroanalysis and in general analytical chemistry. He has made fundamental contributions to the application of electrochemical techniques for the analysis of solid materials, especially in the field of archaeological objects and artefacts [1]. The development of methods of age determination of lead artefacts is one of his research highlights [2-4], another being his research on the nature and preparation techniques of ancient Maya blue [5-8]. Professor DoménechCarbó has been a guest editor of the special issue "Electrochemistry for Conservation Science" [9]. Prof. DoménechCarbó has published more than 200 papers in peer-reviewed journals and he is author or co-author of nine books and book chapters.

\section{References}

1. Doménech-Carbó A (2010) J Solid State Electrochem 14:363

2. Doménech-Carbó A, Doménech-Carbó MT, Peiro MA (2011) Anal Chem 83:5639

3. Doménech-Carbó A (2011) Anal Methods 3:2181

4. Doménech-Carbó A, Doménech-Carbó MT, Peiro MA, Martinez I, Barrio J (2012) J Solid State Electrochem 16:2349

5. Doménech-Carbó A, Doménech-Carbó MT, Vazquez ML (2006) J Phys Chem B 110:6027

6. Doménech-Carbó A, Doménech-Carbó MT, Vazquez ML (2007) Anal Chem 79:2812

7. Doménech-Carbó A, Doménech-Carbó MT, Vazquez ML (2007) J Solid State Electrochem 11:1335

8. Doménech-Carbó A, Doménech-Carbó MT, Vazquez ML (2011) Angew Chem Int Ed 50:5741

9. Doménech-Carbó A (2010) J Solid State Electrochem 14:349

F. Scholz $(\bowtie)$

Institut für Biochemie, Universität Greifswald,

Felix-Hausdorff-Str. 4,

17487 Greifswald, Germany

e-mail: fscholz@uni-greifswald.de 